\title{
The Role of Sexually Transmitted Infections in HIV-1 Progression: A Comprehensive Review of the Literature
}

\author{
Helen M. Chun, ${ }^{1,2}$ Robert J. Carpenter, ${ }^{3}$ \\ Grace E. Macalino, ${ }^{1}$ and Nancy F. Crum-Cianflone ${ }^{1,2,3,4}$ \\ ${ }^{1}$ Infectious Disease Clinical Research Program, Uniformed Services University of the Health Sciences, Bethesda, MD, USA \\ ${ }^{2}$ Naval Health Research Center, San Diego, CA, USA \\ ${ }^{3}$ Division of Infectious Diseases, Naval Medical Center San Diego, 34800 Bob Wilson Drive, Suite 5, San Diego, CA 92134-1005, USA \\ ${ }^{4}$ San Diego State University, San Diego, CA, USA
}

Correspondence should be addressed to Nancy F. Crum-Cianflone; nancy.crum@med.navy.mil

Received 3 January 2013; Accepted 28 May 2013

Academic Editor: Mark R. Dybul

Copyright (c) 2013 Helen M. Chun et al. This is an open access article distributed under the Creative Commons Attribution License, which permits unrestricted use, distribution, and reproduction in any medium, provided the original work is properly cited.

\begin{abstract}
Due to shared routes of infection, HIV-infected persons are frequently coinfected with other sexually transmitted infections (STIs). Studies have demonstrated the bidirectional relationships between HIV and several STIs, including herpes simplex virus-2 (HSV2), hepatitis B and C viruses, human papilloma virus, syphilis, gonorrhea, chlamydia, and trichomonas. HIV-1 may affect the clinical presentation, treatment outcome, and progression of STIs, such as syphilis, HSV-2, and hepatitis B and C viruses. Likewise, the presence of an STI may increase both genital and plasma HIV-1 RNA levels, enhancing the transmissibility of HIV-1, with important public health implications. Regarding the effect of STIs on HIV-1 progression, the most studied interrelationship has been with HIV-1/HSV-2 coinfection, with recent studies showing that antiherpetic medications slow the time to CD $4<200$ cells/ $\mu \mathrm{L}$ and antiretroviral therapy among coinfected patients. The impact of other chronic STIs (hepatitis B and C) on HIV-1 progression requires further study, but some studies have shown increased mortality rates. Treatable, nonchronic STIs (i.e., syphilis, gonorrhea, chlamydia, and trichomonas) typically have no or transient impacts on plasma HIV RNA levels that resolve with antimicrobial therapy; no long-term effects on outcomes have been shown. Future studies are advocated to continue investigating the complex interplay between HIV-1 and other STIs.
\end{abstract}

\section{Introduction}

Individuals infected with human immunodeficiency virus-1 (HIV-1) are often coinfected with other sexually transmitted infections (STIs) due to shared routes of transmission. Over the past decade, there has been mounting evidence of the bidirectional relationship between HIV-1 and other STIs. Initially, studies showed that HIV-1-infected persons may be at risk for more frequent and severe forms of STIs as well as poorer treatment outcomes, especially in cases of concurrent herpes simplex virus-2 (HSV-2) and syphilis infection. More recent data have demonstrated that certain concomitant STIs directly affect HIV-1 transmissibility and may alter HIV1 control and increase progression to AIDS. This review summarizes the current literature regarding the most common STIs (HSV-2, hepatitis B virus, hepatitis C virus, human papilloma virus, syphilis, gonorrhea, chlamydia, and trichomonas) and their impact on HIV-1 progression.

\section{Herpes Simplex Virus Type-2}

Most persons who are infected with HIV-1 are also infected with HSV-2, with published seropositivity rates of $50-90 \%$ [1, 2]. Globally, HSV-2 is the most common cause of genital ulcer disease (GUD), and studies indicate a strong, synergistic relationship between the dual epidemics of HIV-1 and HSV2 [3]. HSV-2 has been shown to play an important role in the spread of HIV-1 (a 3-fold higher risk of acquisition) [4] and has been estimated to contribute over $25 \%$ of incident HIV-1 infections in areas of high HSV-2 prevalence (e.g., Africa) [5]. This increased risk likely occurs through multiple 
mechanisms, including the presence of mucosal disruption and the influx of cells expressing chemokine receptor 5 (CCR5) $[6,7]$. Additionally, there is increased HIV-1 shedding in genital secretions [8] due to local inflammation and the interactions between HSV-2 proteins and the HIV-1 long terminal repeat (LTR) genes and Tat protein [9-11]. HSV2 and HIV-1 can infect the same cells, and HSV-2 proteins ICP-10, ICP-27, and ICP-4 have been shown to upregulate HIV-1 replication by their interactions with the HIV-1 LTR region. Further, HSV-2 protein 16 interacts with the HIV-1 Tat protein and increases HIV-1 transcription [9-13]. As a result, HSV-2 may not only enhance HIV-1 transmission, but it may also have a significant impact on HIV-1 viral control and disease progression among coinfected patients.

Regarding the impact of HSV-2 on the HIV-1 coinfected patient, studies have demonstrated that HSV-2 increases both genital and plasma HIV-1 RNA levels. Initial studies demonstrated that $\mathrm{HSV}-2$ reactivation, with the presence of clinical lesions, was associated with transient increases in genital shedding and levels of plasma HIV-1 RNA [14, 25]. Additionally, HSV-2 replication and shedding occur in the absence of symptoms, suggesting that the impact of HSV-2 extends beyond the timing of clinical HSV-2 lesions. Several studies have demonstrated that asymptomatic HSV2 shedding significantly increases mean genital and plasma HIV-1 RNA levels and results in higher HIV-1 viral load set points $[8,14,26,27]$. These findings suggest that HSV2 coinfection may have important implications for both the spread of HIV-1 and HIV-1 virologic control of the coinfected patient.

Given the potential role of HSV-2 on HIV-1 infection, several studies have evaluated the impact of antiherpetic medications on genital and plasma HIV-1 RNA levels in HIV-1/ HSV-2 coinfected persons (Table 1) [8, 14-24]. A small study by Schacker et al. $(n=12)$ showed that acyclovir reduced plasma HIV-1 RNA levels among coinfected persons, with an average reduction of $48 \%$ [14].

Eight randomized studies subsequently examined the impact of antiherpetic suppressive treatment on plasma HIV-1 RNA levels among HIV-1/HSV-2 coinfected persons not receiving combination antiretroviral therapy (CART) (Table 1). The first study found that valacyclovir $500 \mathrm{mg}$ twice daily versus placebo in a cohort of 136 women in Burkina Faso with HIV-1/HSV-2 coinfection reduced both cervical $(-0.29$ $\log _{10}$ copy $/ \mathrm{mL}, 95 \%$ confidence interval [CI]: $\left.-0.44,-0.15\right)$ and plasma $\left(-0.53 \log _{10}\right.$ copy/mL, 95\% CI: $\left.-0.72,-0.35\right) \mathrm{HIV}-$ 1 RNA levels [8]. Additional studies involving diverse HIV-1 populations are shown in Table 1 . In the largest study to date, Celum et al. examined the effect of long-term acyclovir use in a study designed to determine if HIV-1 transmission rates among discordant couples could be reduced with acyclovir [19]. A randomized, placebo-controlled trial of acyclovir (400 mg twice daily for 102 weeks) among 3,408 African heterosexual couples reported a reduction in the mean plasma concentration of HIV-1 by $-0.25 \log _{10}$ copies $/ \mathrm{mL}$ (95\% CI: $-0.29,-0.22 ; P<0.001)$ in men and women, although the study failed to show a reduction in HIV-1 transmission rates. Mugwanya et al. evaluated whether higher doses of antiherpetic medications were more effective at reducing HIV-1 RNA levels [21]. A randomized, crossover trial of two types and doses of antiherpetic medications was evaluated (valacyclovir $1.5 \mathrm{~g}$ versus acyclovir $400 \mathrm{mg}$ twice daily for 12 weeks) in 32 HIV-1/HSV-2 dually infected Kenyan individuals with CD 4 cell counts $>250$ cells $/ \mathrm{mL}$ and not on CART. Mean plasma HIV-1 levels were significantly lower in the valacyclovir compared with the acyclovir arm: -0.62 $\log _{10}$ copies/mL (95\% CI: $-0.68,-0.55 ; P<0.001$, a $76 \%$ decrease), and valacyclovir decreased the viral load by $>1$ log compared with baseline pretreatment values. This study suggested that higher doses of antiherpetic medications may offer greater benefit in reducing HIV-1 RNA levels and revealed no increase in adverse events using the higher dose.

In summary, these studies examined both male and female HIV-1/HSV-2 coinfected patients from a variety of geographic locations and demonstrated that antiherpetic medications (typically using 400-800 mg of acyclovir twice daily or valacyclovir $500 \mathrm{mg}$ twice daily) for 1-3 months reduced the plasma HIV-1 levels by 0.26 to $0.47 \log _{10}$ copies/ $\mathrm{mL}$ among HIV-1 patients not receiving CART.

A meta-analysis recently summarized the randomized evidence (2000-2009) regarding the association between antiherpetic medications and plasma HIV-1 RNA levels [28], with a summary effect estimate of -0.33 (95\% CI: -0.56 , $-0.10) \log _{10}$ copies, an approximate halving of HIV-1 plasma viral load. Of note, characteristics associated with a larger decrease in HIV-1 viral load included older median age, valacyclovir use, and higher compliance rates [28]. These randomized studies clearly show the benefit of antiherpetic medications in reducing HIV RNA levels in the setting of asymptomatic HSV-2 coinfection. The reduction in HIV-1 RNA loads by these agents is due to suppression of HSV2 replication and its interaction with the HIV-1 virus, as described above, as well as the potential direct antiretroviral effects of acyclovir [29-31].

Unlike prior studies that examined the impact of antiherpetic therapy among HIV-1 patients not receiving CART, a randomized, double-blind, and placebo-controlled trial of valacyclovir $500 \mathrm{mg}$ twice a day in HIV-1/HSV-2-infected women on CART, with a similar design as the study by Nagot et al. [8], showed no significant impact on the frequency or quantity of genital HIV-1 RNA [22]. The plasma HIV-1 RNA was reduced $\left(-0.41 \log _{10}\right.$ copy $\left./ \mathrm{mL}\right)$, although this did not reach statistical significance, perhaps due to small sample size. Further studies are needed to examine the benefit of antiherpetic medication on systemic HIV-1 control in this setting.

While these studies demonstrated that antiherpetic therapy reduces genital and plasma HIV-1 RNA levels among patients not receiving CART $[8,14-21]$, whether this therapy could slow HIV-1 clinical progression was not specifically examined. Since higher plasma HIV-1 RNA levels are associated with faster HIV-1 disease progression [32], it was hypothesized that HSV-2 suppression may slow HIV-1 progression. A recent review noted that a reduction in HIV-1 viral load of $0.3 \log _{10}$ or $0.5 \log _{10}$ may slow HIV-1 clinical progression by $25 \%$ to $44 \%$, respectively [33]. Additionally, during early trials of antiretroviral therapy (ART), acyclovir was associated with increased survival [34]. Hence, clinical trials 


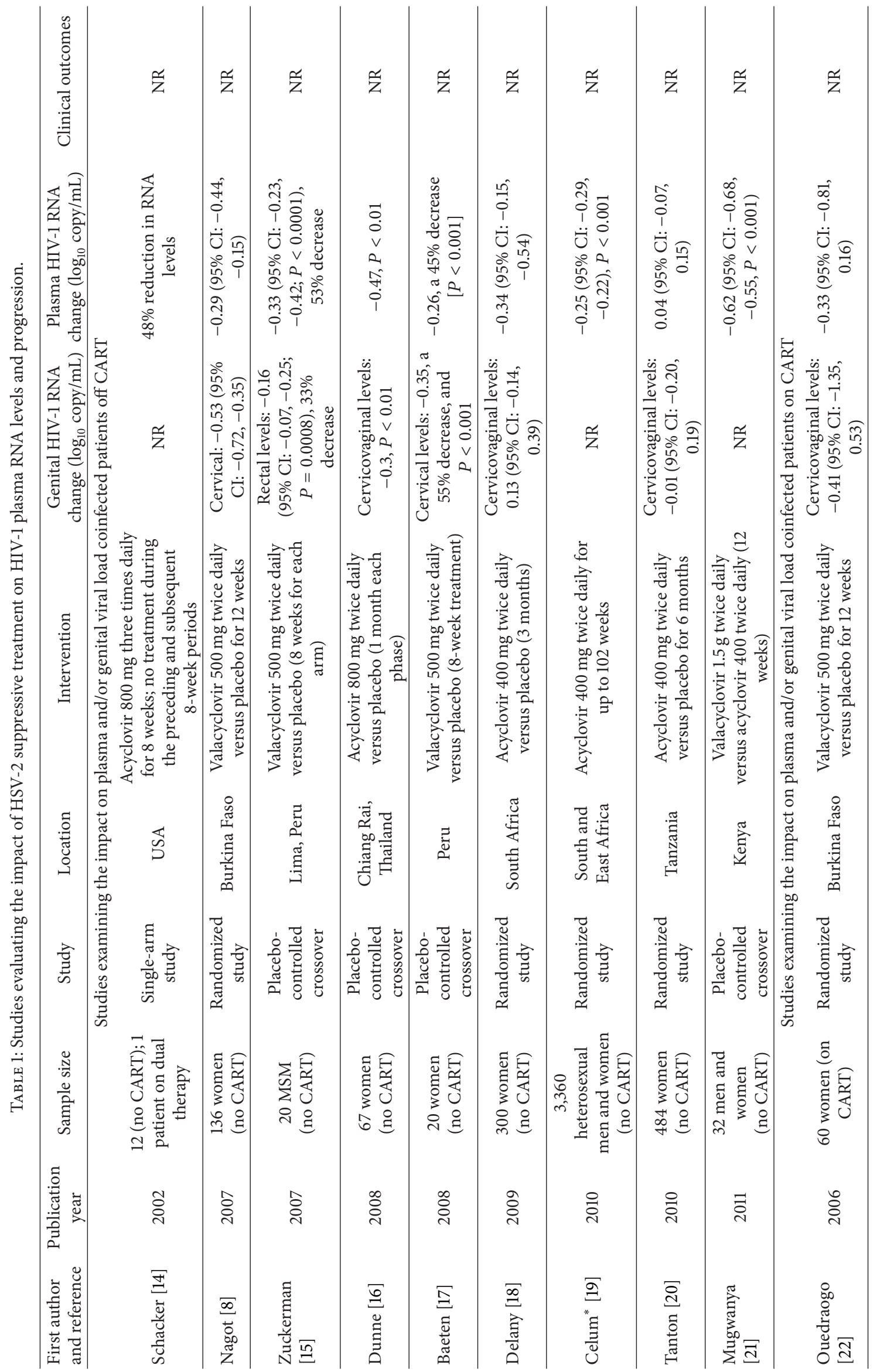




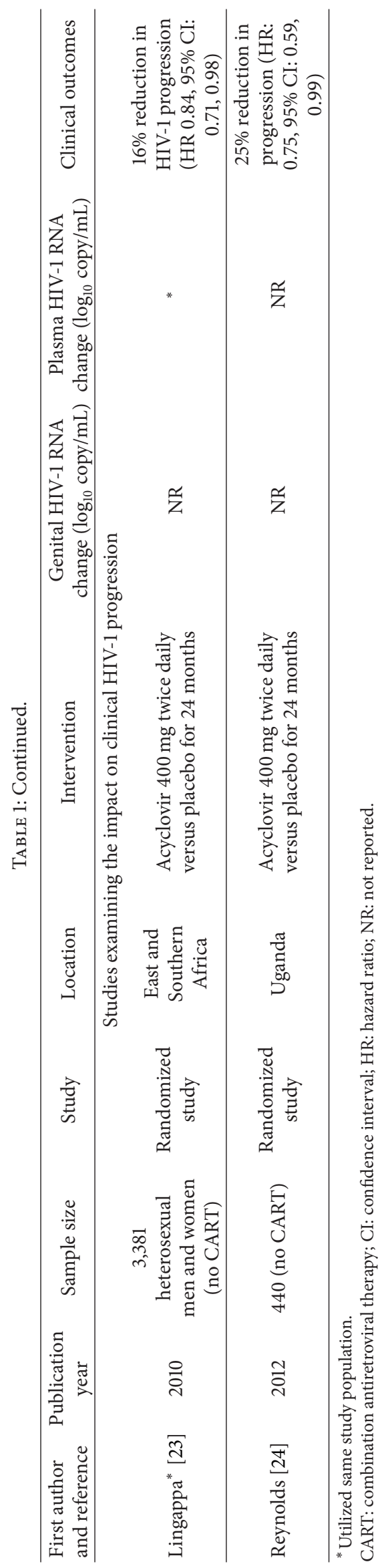


were undertaken to determine if the use of acyclovir could slow HIV-1 progression.

Lingappa et al. [23] randomized 3,381 HIV-1/HSV-2 dually infected heterosexuals to acyclovir $400 \mathrm{mg}$ twice daily or placebo for 24 months (Table 1). All participants had a CD4 cell count $\geq 250$ cells $/ \mu \mathrm{L}$ and were not receiving CART. HIV- 1 progression was defined as a CD 4 cell count $<200$ cells $/ \mu \mathrm{L}$, CART initiation, or a nontrauma-related death. The receipt of acyclovir was associated with a $16 \%$ reduction in HIV-1 progression (hazard ratio $[\mathrm{HR}]=0.84,95 \% \mathrm{CI}: 0.71,0.98$, and $P=0.03)$, as well as with a delayed risk of reaching a CD4 cell count $<350$ cells $/ \mu \mathrm{L}(\mathrm{HR}=0.81,95 \%$ CI: $0.71,0.93$, and $P=0.002$ ). Assuming that the incidence of endpoints remained constant over time, acyclovir would have delayed the median time to an endpoint by estimated 10.7 months. A second study on HIV-1 progression [24] investigated the effect of daily suppressive acyclovir on HIV-1 disease progression in patients with CD 4 cell counts of $300-400$ cells $/ \mu \mathrm{L}$ who were not receiving CART. Participants were randomized to acyclovir $400 \mathrm{mg}$ twice daily or placebo and followed for 24 months. The treatment group had a $25 \%$ reduced risk of developing a CD4 cell count $<250$ cells $/ \mu \mathrm{L}$ or initiating of CART for WHO stage 4 disease. In addition to these studies $[23,24]$, one study evaluated the impact of acyclovir (400 mg twice daily) versus placebo on the viral load set point during early HIV-1 infection $(n=76)$ but found no significant effect [35].

Overall, these studies provide strong evidence that antiherpetic medications reduce both plasma and genital HIV-1 RNA levels among chronically infected HIV-1 patients who are coinfected with HSV-2. Antiherpetic medication may offer an important and viable strategy to reduce HIV-1 progression in the setting of limited CART availability or among patients wishing to remain off CART. Advantages of antiherpetic medication use in these settings include its low cost (i.e., available as a generic medication), excellent tolerability, lack of need for specific laboratory monitoring, and low frequency of adverse events. Therapy is most advantageous when utilized continuously, since the interruption of therapy is associated with viral rebound [21]. The effect of antiherpetic medication on plasma HIV-1 concentrations can be seen within a week of initiation [21], with no reduction in efficacy noted over time [23]. The added value of antiherpetic medications concurrently with CART or in other clinical scenarios (at time of seroconversion or among HIV-2 patients) requires further evaluation.

\section{Hepatitis B Virus}

Hepatitis B virus (HBV) is more common in HIV-1-infected individuals than in the general population due to shared risk factors for acquisition [36-39], with published rates of 6$14 \%$ having concurrent chronic HBV [40]. Current evidence suggests that HIV-1 infection modifies the course of HBV with an adverse impact on HBV-related liver disease progression, including higher serum HBV DNA polymerase activity; lower rates of loss of serum hepatitis B e antigen (HBeAg); and increased risk of cirrhosis, liver-related mortality, and hepatocellular carcinoma, especially among patients with lower CD4 cell counts [36, 41-46]. HBV infection is also more likely to become chronic in those coinfected with HIV-1 [43].

Overall, studies evaluating the influence of $\mathrm{HBV} / \mathrm{HIV}$ coinfection on HIV RNA suppression, immunologic CD4 cell count recovery, and clinical outcomes in individuals on HAART have been limited and conflicting, with several studies finding no substantial impact of HBV coinfection on immunologic or HIV virologic responses to ART [4653]. Other studies, however, have shown a significant impact on ART outcomes [54-56]. Conflicting findings from these studies may be attributable to the inconsistent choice of viral markers for study eligibility [46, 55], being observational versus prospective studies, having limited follow-up time [46, 55], small numbers of HIV/HBV coinfected patients, limited mortality data [57], varying HBV disease characteristics (HBeAg status, HBV DNA), varying endemicity of HBV, HCV coinfection, lack of data on opportunistic infections [53], and lack of data to specify if patients were receiving HBV-active ART. Clinical studies prior to the general availability of CART evaluating the impact of HBV on HIV1 progression have also shown inconsistent results [48, 49, $51,54,56,58-60]$. Some studies found no differences in HIV-1 progression between those with and without chronic HBV [36, 53, 59, 61], while other studies have shown that chronic HBV may negatively impact HIV-1 progression with a significant increased risk of AIDS or death [55, 62-64]. HBV is thought to mediate destruction of $\mathrm{CD} 4$ cells through $\mathrm{T}$ cell activation or splenic sequestration seen in advanced liver disease [53].

Studies on CD4 cell counts at and after ART initiation are conflicting. Some have shown that HIV-1/HBV coinfected patients have significantly lower CD4 cell counts at ART initiation compared with individuals infected with HIV-1 alone $[46,48,53,55,65,66]$. In a study from China, HBeAg positivity, rather than HBV DNA level, was associated with lower cell counts in chronic HIV-1/HBV coinfected patients [65]. Other studies have not detected differences in CD4 cell counts prior to ART initiation $[49,54,67]$. In one study, individuals with occult hepatitis B (HBV DNA present in the absence of hepatitis B surface antigen) demonstrated lower CD4 cell counts as compared to individuals without occult hepatitis B [68].

Some studies evaluating CD4 cell count responses in coinfected individuals after ART found no differences in CD4 gains in HIV-1/HBV coinfected versus HIV-1 monoinfected individuals $[54,57,69]$, while other studies have shown a negative impact of HBV on CD4 cell count recovery. However, the studies by Law and Hawkins showed no difference by 48 weeks and borderline significance at 12 months, respectively $[46,55,56,67]$. Individuals with $\mathrm{HBeAg}$-positive status at ART initiation and HBV DNA $\geq 20,000 \mathrm{IU} / \mathrm{mL}$ were significantly associated with lower $\mathrm{CD} 4$ cell counts, but $\mathrm{HBV}$ status and HBV DNA level were not shown to affect CD4 cell count rise [53]. One hypothesis why lower CD4 cell counts may be observed with HBeAg and higher HBV DNA is the possibility that HBV replication increases HIV-1 replication, in turn lowering CD4 cell counts based on in vitro data showing HBV X protein acting as a transactivator of HIV-1 
transcription, but these data have not been demonstrated in vivo [70-72]. An alternative explanation is that HBV leads to increased apoptosis of CD4 cells through increased Tcell activation or an alternation in cytokines that leads to decreased production or destruction of CD4+ T cells [53].

In addition to the potential effects on CD4 cell counts, several studies have examined the impact of coinfection on the plasma HIV-1 viral load. Evaluation of HIV-1 viral load at ART initiation has not shown any differences, but there are conflicting data on virologic suppression, with some studies showing no differences in the proportion of individuals achieving virologic suppression over time $[55,57$, 65-67]. For example, a lower proportion of HBeAg-positive individuals achieved VS (HIV-1 VL $\leq 400$ copies/mL) at 24 weeks compared with HBeAg-negative or HIV-1 monoinfected individuals, but no differences were observed by 48 weeks [53]. Additionally, in this study from Nigeria, the proportion of patients with virologic suppression (HIV-1 $\mathrm{VL} \leq 400$ copies $/ \mathrm{mL}$ ) at 6 months was $67 \%$ versus $70 \%$ in the HIV-1/HBV coinfected and HIV-1 monoinfected groups, respectively [53]. Finally, one study showed a higher rate of virologic failure in $\mathrm{HBV} / \mathrm{HIV}-1$ coinfected patients, although the cause for the higher rate was not clear [54].

There have been no reported differences in the incidence of new AIDS-defining events among HBV/HIV-1 coinfected compared with HIV-1 monoinfected individuals [46, 54, 73]. Nevertheless, all-cause mortality has been shown to be higher, most commonly attributable to liver-related deaths [42, 46, 73]. A meta-analysis (including 11 studies with 12,382 patients) showed a significantly increased risk for all-cause mortality in coinfected patients [73]. Studies evaluating the impact of HBV-active ART on mortality are limited. One study conducted in an urban Tanzanian cohort showed a significantly higher risk of mortality $(\mathrm{HR}=1.28$, 95\% CI: $1.02-$ 1.61, and $P<0.03$ ) in coinfected patients compared with monoinfected HIV-1 patients on ART regimens that did not contain tenofovir (TDF), but no difference in mortality among the two groups with the use of TDF-containing regimens [55].

Given the findings from a recent multinational cohort showing HIV-1/HBV coinfected individuals have significantly lower CD4 cell counts than monoinfected patients, determining the HBV status at HIV diagnosis and prior to CART initiation should be a priority [66]. Despite the dramatic reductions in morbidity and mortality in the CART era, lower survival rates in $\mathrm{HBV} / \mathrm{HIV}-1$ coinfected individuals are seen, with death attributable to chronic hepatic complications assuming more prominence in the era of CART [54]. Given the differences in findings from the studies described above, further evaluations of the long-term immunologic and virologic responses to ART in $\mathrm{HBV} / \mathrm{HIV}-1$ coinfected individuals compared with HIV-1 monoinfected individuals are needed to further our understanding of the effect of HBV on HIV-1 and ART response and long-term outcomes.

\section{Hepatitis C Virus}

Hepatitis C virus (HCV) is a common blood-borne pathogen among HIV-1-positive intravenous drug users, with recent increasing rates via sexual transmission among men who have sex with men (MSM) [74-76]. The negative impact of HIV-1 infection on the natural history of HCV infection is well established; $\mathrm{HCV}$-associated liver disease, including fibrosis, cirrhosis, and end-stage liver disease, is accelerated among HIV-1-infected populations. For example, progression to cirrhosis is 2-3 times higher in coinfected than monoinfected individuals, with a third of coninfected patients estimated to progress to cirrhosis in less than 20 years [77]. An increased risk of liver-related deaths among coinfected compared with HCV monoinfected drug users despite CART use has also been reported from a recent 20year prospective study [78].

While the mechanism to explain the adverse impact of HIV-1 on liver disease in HCV-infected individuals is not clear to date, it likely includes immune activation, apoptosis, and diminished HCV-specific T-cell responses [79-81]. Increased tissue damage in coinfected populations may be due to the accumulation of cytotoxic CD8 cells in the liver that may increase inflammatory mediators [82, 83]. HIV-1 replication has been noted in hepatocytes and hepatic stellate cells $[81,84,85]$, with promotion of collagen expression and secretion of proinflammatory cytokines [85]. Insulin resistance appears to be critical in liver steatosis and liver disease progression, although the data are not definitive if it is more prevalent among coinfected [86] or monoinfected individuals [87].

The debate as to whether HCV has a negative impact on HIV-1 disease progression continues. While many studies have shown higher mortality among HIV-1/HCV coinfected individuals compared with those with mono-infection, a meta-analysis conducted in 2009 that included 100,000 patients across 30 studies found no increase in mortality in coinfected patients prior to the CART era. After CART, this study found an increased risk for overall mortality but not for AIDS-defining conditions [88]. However, some studies have found an increased risk of AIDS and AIDS-related infections; data from a cohort in Italy reported a twofold increase in AIDS risk among coinfected participants [89], with increases in bacterial and mycotic infections. Similarly, a US cohort of HIV-1-positive women also found an almost twofold increase in risk of AIDS for those never on CART [90].

Coinfected patients have been found to have high levels of T-cell activation even following CART compared with monoinfected patients [90-92]. Chronic immune activation may cause immune dysfunction and cytokine production, leading to enhanced HIV-1 and HCV replication and lower CD4 cell counts [91]. In one study of HIV-1-infected women, $\mathrm{HCV}$-viremic compared with $\mathrm{HCV}$-uninfected women had high levels of activated CD8 T cells associated with incident AIDS, and AIDS in both groups was associated with CD4 activation [90, 91], while suppression of HCV with therapy reduces activation [92]. HCV coinfection may increase immune activation, leading to CD4 cell apoptosis in HIV-1-untreated patients and more rapid progression to severe immunodeficiency [93]. However, the impact of HCV infection on CD4 cell recovery following CART is conflicting; some reports note a poorer CD4 response in coinfected compared with monoinfected patients [94], while others do not [93-98]. 
It is important to consider the timing of CART initiation relative to anti-HCV therapy for coinfected patients. CART may slow liver disease progression and might therefore be initiated earlier in coinfected than in HIV-1 monoinfected patients $[99,100]$. Conversely, CART may increase fibrosis in coinfected patients through cumulative hepatotoxicity [99, 101]. Recent guidelines recommend that CART generally be initiated first to slow liver disease progression and increase CD4 cell count, bearing in mind that some drugs should be avoided while others should be monitored for hepatotoxicity [102].

\section{Human Papilloma Virus}

Human papilloma virus (HPV) is known to be the causative agent for urogenital warts, oropharyngeal cancer, cervical dysplasia and cancer in women, and anal dysplasia and cancer in men and women [103-106]. Cervical and anal cancers develop from cervical intraepithelial neoplasia (CIN) and anal intraepithelial neoplasia (AIN), respectively. Most studies in the medical literature demonstrate adverse effects of HIV-1 infection on HPV disease and its progression. In fact, HIV-1-infected persons tend to have larger and multicentric venereal warts, have more anal and cervical dysplasia, and tend to be infected with multiple HPV subtypes [107-110].

HIV-1-infected persons are also at higher risk for intraepithelial neoplasia and cancers. Women with HIV-1 infection are approximately 30 times more likely to develop CIN (compared with HIV-1-uninfected women) [107], and MSM with HIV-1 infection are approximately 6-9 times more likely to develop AIN (compared to HIV-1-negative MSM) [111]. Of note, anal sex is not a prerequisite for AIN. Conley et al. found the following AIN prevalence among their HIV-1infected cohort: $9-31 \%$ in MSM, 3-17\% in women, and 1-9\% in men who have sex with women [112], while another study of HIV-1-infected women found an AIN prevalence of 33\% over 3 years of follow-up [113]. HIV-1-infected persons are also at higher risk of developing anal cancer compared with their HIV-1-uninfected counterparts. Crum-Cianflone et al. found anal cancer incidence rate of 128/100,000 among a large cohort of HIV-1-infected persons compared with 1.4/100,000 for men in the general US population [114].

There are limited data implicating HPV infection as a risk factor for acquiring HIV-1 infection [115, 116] with a systematic review in 2012 (examining six studies in women and two in men) showing a twofold increased risk of HIV-1 acquisition in women, with similar trends in the men [115]. However, regarding the potential direct effect of HPV on HIV-1 infection control (e.g., HIV RNA levels) or noncancerrelated clinical progression (e.g., time to AIDS), our review did not identify any published studies to date.

\section{Syphilis}

Syphilis represents the second most common cause of GUD among HIV-1-infected persons, with documented increasing rates of syphilis among HIV-1-infected persons over the past decade, especially among MSM [117-119]. Multiple studies have confirmed that syphilis infection is associated with an increased risk of acquiring and transmitting HIV-1 [120, 121], with mechanisms including the disruption of the mucosa and the influx of CCR5+ cells. Regarding the impact of HIV-1 infection on syphilis, studies have shown that it adversely affects the serologic response to syphilis treatment, especially at lower CD 4 cell counts $<200$ cells $/ \mu \mathrm{L}$, but that CART reduces the failure rate $[122,123]$.

Several studies have evaluated the impact of syphilis on the natural history of HIV-1 infection. Initial studies focused on the effect of syphilis coinfection on CD4 cell counts and HIV-1 RNA plasma levels. The first published report demonstrated small changes in HIV-1 RNA levels and CD4 counts associated with syphilis infection; Buchacz et al. showed that among 52 HIV-1-infected men in California with primary or secondary syphilis, within-person changes in viral loads were slightly higher during versus prior to the syphilis infections (mean $0.22 \log _{10}$ copies $/ \mathrm{mL}, P=0.02$ ) that decreased after therapy $\left(-0.10 \log _{10}\right.$ copies $\left./ \mathrm{mL}, P=0.52\right)$ [124]. A small decrease in CD4 cell counts was also noted during infection $(-62$ cells $/ \mu \mathrm{L}, P=0.04)$, with recovery after treatment $(+33$ cells $/ \mu \mathrm{L}, P=0.23)$.

A second study was conducted in Denmark among 41 HIV-1-infected persons with primary or secondary syphilis. This study found an increase in HIV-1 RNA levels and a reduction in CD4 cell counts among those with an initial CD4 count of $>500$ cells $/ \mu \mathrm{L}$ [125], which improved after the treatment of syphilis. Additionally, a study from Spain demonstrated that, among 118 coinfected patients, syphilis resulted in similar CD4 cell and viral load effects among one-third of patients [126]. Specifically, among those with a detectable viral load before syphilis, infection resulted in an increase in HIV-1 viral load of $1.03 \log _{10}$ (IQR 0.64-1.32), and 25\% of those initially suppressed had viral load detection during syphilis infection. Mean CD4 counts were lower during syphilis than before ( 496 versus 590 cells $/ \mu \mathrm{L}, P<0.001$ ) and increased after treatment (597 versus 509 cells $/ \mu \mathrm{L}, P<0.001$ ) [126]. Of note, $>50 \%$ of patients in each of these studies [124126] were on ART. Although most studies have shown that syphilis adversely impacts HIV-1 control, some studies have shown no effect, including a study of 38 coinfected persons from Italy [127]. Further, a study examining 63 coinfected persons and a group of controls (without an STI) from London showed no major impact on HIV-1 RNA levels in the blood or semen, but it did show changes in CD4 cell counts among early latent syphilis cases [128].

The most recent study examined a cohort of HIV-1 patients 1998-2006 and compared 282 coinfected patients with 1,233 syphilis-free matched HIV-1 controls [129]. This study showed that plasma HIV-1 RNA increases (adjusted odds ratio $=1.87,95 \%$ CI: $1.40-2.49)$ and CD4 cell decreases ( -28 cells $/ \mu \mathrm{L}, P=0.001$ ) were more likely among those with syphilis infection. Further, this study demonstrated the association between syphilis and viral rebound among patients who were receiving effective CART regimens. These findings were independent of the syphilis stage or initial CD4 cell count. The potential mechanism of these effects has been hypothesized to be a result of immune activation of host 
cells, increase in cytokine secretion, and upregulation of chemokine coreceptors $[126,130]$.

In order to evaluate the potential effect of syphilis on HIV1 progression (time to AIDS or death), a study by Weintrob et al. prospectively evaluated 2,239 HIV-1 seroconverters not receiving ART with confirmed (9.2\%) and probable (2.9\%) syphilis [131]. This study, with 7,827 person-years of followup, however, found no impact of syphilis on HIV-1 disease progression ( $\mathrm{HR}=0.99,95 \% \mathrm{CI}$ : $0.73-1.33)$. Overall, syphilis increases the risk of HIV-1 transmission and leads to transient increases in HIV-1 RNA plasma levels and decreases in CD4 counts among a subset of patients regardless of the receipt of ART. Treatment of syphilis leads to resolution of the viral load and $\mathrm{CD} 4$ cell changes with no apparent long-term impact on HIV-1 progression.

\section{Gonorrhea and Chlamydia Infections}

Neisseria gonorrhoeae (GC) and Chlamydia trachomatis (CT) are bacteria that may be sexually transmitted from person to person and cause pharyngitis, cervicitis/urethritis, epididymitis, proctitis, and pelvic inflammatory disease. Both men (including MSM) and women often harbor asymptomatic infection [132]. The interrelationships of these bacteria and HIV-1 are complex, but exacerbation of either infection and facilitation of HIV-1 transmission have been demonstrated at some, but not all, mucosal surfaces. HIV1-infected persons may have reduced clearance of these infections at mucosal sites. For example, interferon gamma (IFN- $\gamma$ ) is thought to be important for the clearance of CT infection [133-135]; however, studies suggest that HIV1-infected persons secrete significantly less (IFN- $\gamma$ ) [136], suggesting impaired elimination of these infections.

Concurrent bacterial STIs have been shown to increase HIV-1 shedding at mucosal sites, with subsequent treatment resulting in a decrease in the amount of HIV-1 present in genital fluids [137-140]. A study comparing seminal HIV-1 levels among HIV-1 patients (not on CART) with GC/CT, nonspecific urethritis, or no STI found that the presence of GC or CT resulted in a fivefold increase in seminal HIV-1 RNA levels that were not observed in the other groups [138]. Following antibiotic therapy, HIV-1 RNA levels decreased in the GC/CT group. In a second study, the effects of GC/CT were evaluated among an HIV-1 cohort on ART, finding that most patients with undetectable plasma HIV-1 viral loads maintained no detection of HIV-1 in seminal fluid after acquiring GC/CT [139]. Similarly, a study of MSM receiving CART who had a bacterial STI showed that the plasma HIV-1 RNA level was the only significant correlate of rectal viral load in a model that included concurrent GC and CT infection [141]. However, presence of GC or CT infection strengthened the correlation between plasma and rectal viral load; thus these coinfections may enhance rectal shedding in setting ongoing viral replication. These data suggest that the impact of GC/CT urethritis on changes in genital HIV-1 RNA levels is limited in the setting of effective ART, but substantial in patients not receiving CART and who have detectable plasma HIV-1 viral loads, potentially enhancing HIV-1 infectivity.
Regarding the effect of GC/CT on HIV-1 plasma viral load, Nkengasong et al. studied HIV-1-infected female sex workers in Africa and found that STIs, specifically ulcerative disease and GC, caused a 2.5-fold rise in HIV-1 plasma viral load [142]. They also found that those with STIs tended to demonstrate more CD4 cell activation and increased proinflammatory cytokines, but they did not reach statistical significance. Anzala et al. also studied female sex workers in Africa [143] and found that acute infection with GC caused transient increases ininterleukin- (IL-) 4, IL-6, IL-10, soluble tumor necrosis factor- (TNF-) $\alpha$, and HIV-1 plasma viral load and a decline in CD4 cell counts, which returned to baseline after the acute bacterial infection was treated. They also observed similar changes in women with acute pelvic inflammatory disease.

These data suggest that coinfection with bacterial STIs may acutely impact HIV-1 control and increase transmissibility of the virus. To date, there are no data to suggest that GC/CT infections impact the long-term progression of HIV1 disease.

\section{Trichomoniasis}

Trichomoniasis, caused by the protozoan parasite, Trichomonas vaginalis, is the most common curable, nonviral STI worldwide [144-147], with over 170 million cases per year [148]. T. vaginalis is a highly prevalent STI among HIV-1infected patients $[149,150]$, and there is a high frequency of asymptomatic or subclinical infection [151-153]. T. vaginalis infections are not currently reported to state agencies in the United States, limiting available prevalence data. The advent of polymerase chain reaction (PCR) testing, as a much more sensitive diagnostic technique, has allowed for a greater understanding of the global epidemiology of $T$. vaginalis and has heightened the awareness of the potential impact trichomoniasis has on HIV-1 transmission and female reproductive health [145].

Data have demonstrated that $T$. vaginalis infection enhances HIV-1 transmission [151, 154-156], with risk increased up to threefold $[148,154,155,157-159]$. One recent study using mathematical modeling found $23 \%$ of HIV-1 transmission events from HIV-1-infected women may be attributable to T. vaginalis infection [160]. Proposed mechanisms by which $T$. vaginalis infection may increase HIV1 infection include inducing the inflammatory response of vaginal, exocervix, and urethral epithelia; disrupting mucosal barrier function; recruitment of CD4 lymphocytes and macrophages; development of microhemorrhages; degrading secretory leukocyte protease inhibitors; and enhancing susceptibility to bacterial vaginosis or other abnormal vaginal flora that may increase the risk of HIV-1 acquisition [161-164].

The hemorrhages and inflammation produced by T. vaginalis infection in an HIV-1-infected individual can increase the level of virus-laden body fluids and/or the numbers of HIV-1-infected macrophages and lymphocytes in genital areas, thereby amplifying the probability of HIV-1 exposure and transmission [161]. Increased cervical shedding of HIV-1 has been shown to be associated with cervical inflammation 
[165, 166]. Similarly, studies have shown that men with urethritis have higher HIV-1 RNA concentrations in semen if infected with T. vaginalis than those with urethritis of an unidentified cause [167]. Data regarding HIV-1 patients receiving ART have shown that detection of vaginal HIV-1 RNA was not different before or during a $T$. vaginalis infection, suggesting that CART generally maintains low or undetectable genital HIV-1 levels, even in the presence of this STI [168].

Studies have shown that treatment for trichomoniasis significantly reduces HIV-1 RNA genital shedding [169-171]. These data have important implications for the importance of screening and early treatment of trichomoniasis to decrease viral shedding and possibly decrease HIV-1 transmission risk [170].

The impact of T. vaginalis infection on HIV-1 outcomes (immunologic, virologic, and clinical [AIDS or death]) is less well defined. Given the impact of both HIV-1 and T. vaginalis on immune activation locally and systemically, it can be hypothesized that coinfection alters immune responses and may alter either CD4 cell count or HIV-1 viral load, but there are no data to support this. Similarly, the coinfection's interaction with the immune system and the enhanced or altered susceptibility to other infections that impact HIV-1 outcomes are plausible.

Despite the limited data on the impact of $T$. vaginalis infection on HIV-1 progression, it is clear that $T$. vaginalis has a substantial impact on the spread of HIV-1. The potentially large reservoir of asymptomatic carriers, the availability of treatment for trichomoniasis, and the overlap of HIV-1 epidemics throughout communities and the world should prompt policy makers to consider screening and treatment programs for $T$. vaginalis and prompt greater research in understanding the impact trichomoniasis has on HIV-1 outcomes.

\section{Summary}

Complex bidirectional relationships exist between HIV-1 and other STIs. While the impact of HIV-1 infection on the clinical presentations and treatment outcomes of STIs is well known, fewer data exist regarding the impact of concurrent STIs on HIV-1 progression (virologic, immunologic, and clinical) and acquisition, with most studies focusing on HIV1 shedding at genital mucosal sites. Studies have shown that the presence of some STIs, both ulcerative and nonulcerative, increases genital HIV-1 RNA levels and enhances the transmissibility of HIV-1, with important public health implications. Studies have also shown that these effects are substantially limited among HIV-1 patients receiving effective ART, suggesting an important role for early ART initiation. Additionally, safe-sex counseling, routine STI screening, and early treatment are critically important.

Regarding the effect of STIs on HIV-1 progression, the most studied interrelationship has been HIV-1/HSV-2 coinfection. Studies have shown that HSV-2 increases genital and plasma HIV-1 RNA levels and that the use of antiherpetic medications reduces these effects and reduces HIV-1 progression among coinfected patients not receiving CART. The impact of other STIs on HIV-1 progression is less clear, but those coinfected with HBV or HCV appear to have higher mortality rates (predominantly $\mathrm{HBV} / \mathrm{HCV}$ related), during the CART era, but not necessarily higher rates of AIDS progression. For other treatable, nonchronic STIs (i.e., syphilis, gonorrhea, and chlamydia), their impact on HIV-1 RNA levels and CD4 cell counts are typically transient and resolve with antimicrobial therapy. Future studies are needed to continue to define the rates of coinfections in various HIV1 populations, the pathogenesis and impact of STIs on HIV1 outcomes, and the role of STI therapy on reducing HIV-1 progression.

\section{Conflict of Interests}

The authors have no financial interest in this work. All authors contributed to the content of the paper and concurred with the decision to submit it for paper. The content and views expressed in this publication are the sole responsibility of the authors and do not necessarily reflect the views, policies of the NIH, the Department of Health and Human Services, US Army, Navy, Air Force, Department of Defense, or the US Government. Mention of trade names, commercial products, or organizations does not imply endorsement by the US Government.

\section{References}

[1] H. Weiss, "Epidemiology of herpes simplex virus type 2 infection in the developing world," Herpes, vol. 11, supplement 1, pp. 24A-35A, 2004.

[2] J. S. Smith and N. J. Robinson, "Age-specific prevalence of infection with herpes simplex virus types 2 and 1: a global review," Journal of Infectious Diseases, vol. 186, no. 1, pp. S3-S28, 2002.

[3] R. V. Barnabas and C. Celum, "Infectious co-factors in HIV-1 transmission herpes simplex virus type-2 and HIV-1: new insights and interventions," Current HIV Research, vol. 10, pp. 228-237, 2012.

[4] E. E. Freeman, H. A. Weiss, J. R. Glynn, P. L. Cross, J. A. Whitworth, and R. J. Hayes, "Herpes simplex virus 2 infection increases HIV acquisition in men and women: systematic review and meta-analysis of longitudinal studies," AIDS, vol. 20, no. 1, pp. 73-83, 2006.

[5] L. J. Abu-Raddad, A. S. Magaret, C. Celum et al., "Genital herpes has played a more important role than any other sexually transmitted infection in driving HIV prevalence in Africa," PLoS ONE, vol. 3, no. 5, Article ID e2230, 2008.

[6] A. L. Cunningham, R. R. Turner, and A. C. Miller, "Evolution of recurrent herpes simplex lesions. An immunohistologic study," Journal of Clinical Investigation, vol. 75, no. 1, pp. 226-233, 1985.

[7] J. S. Sheffield, G. D. Wendel Jr., D. D. McIntire, and M. V. Norgard, "Effect of genital ulcer disease on HIV-1 coreceptor expression in the female genital tract," Journal of Infectious Diseases, vol. 196, no. 10, pp. 1509-1516, 2007.

[8] N. Nagot, A. Ouédraogo, V. Foulongne et al., "Reduction of HIV-1 RNA levels with therapy to suppress herpes simplex virus," The New England Journal of Medicine, vol. 356, no. 8, pp. 790-799, 2007. 
[9] D. M. Margolis, A. B. Rabson, S. E. Straus, and J. M. Ostrove, "Transactivation of the HIV-1 LTR by HSV-1 immediate-early genes," Virology, vol. 186, no. 2, pp. 788-791, 1992.

[10] J. D. Mosca, D. P. Bednarik, N. B. K. Raj et al., "Activation of human immunodeficiency virus by herpesvirus infection: identification of a region within the long terminal repeat that responds to a trans-acting factor encoded by herpes simplex virus 1," Proceedings of the National Academy of Sciences of the United States of America, vol. 84, no. 21, pp. 7408-7412, 1987.

[11] M. P. Golden, S. Kim, S. M. Hammer et al., "Activation of human immunodeficiency virus by herpes simplex virus," Journal of Infectious Diseases, vol. 166, no. 3, pp. 494-499, 1992.

[12] M. A. Albrecht, N. A. DeLuca, R. A. Byrn, P. A. Schaffer, and S. M. Hammer, "The herpes simplex virus immediate-early protein, ICP4, is required to potentiate replication of human immunodeficiency virus in CD4+ lymphocytes," Journal of Virology, vol. 63, no. 5, pp. 1861-1868, 1989.

[13] L. S. Kucera, E. Leake, N. Iyer, D. Raben, and Q. N. Myrvik, "Human immunodeficiency virus type 1 (HIV-1) and herpes simplex virus type 2 (HSV-2) can coinfect and simultaneously replicate in the same human CD4+ cell: effect of coinfection on infectious HSV-2 and HIV-1 replication," AIDS Research and Human Retroviruses, vol. 6, no. 5, pp. 641-647, 1990.

[14] T. Schacker, J. Zeh, H. Hu, M. Shaughnessy, and L. Corey, "Changes in plasma human immunodeficiency virus type 1 RNA associated with herpes simplex virus reactivation and suppression," Journal of Infectious Diseases, vol. 186, no. 12, pp. 1718-1725, 2002.

[15] R. A. Zuckerman, A. Lucchetti, W. L. H. Whittington et al., "Herpes simplex virus (HSV) suppression with valacyclovir reduces rectal and blood plasma HIV-1 levels in HIV-1/HSV2-seropositive men: a randomized, double-blind, placebocontrolled crossover trial," Journal of Infectious Diseases, vol. 196, no. 10, pp. 1500-1508, 2007.

[16] E. F. Dunne, S. Whitehead, M. Sternberg et al., "Suppressive acyclovir therapy reduces HIV cervicovaginal shedding in HIVand HSV-2-infected women, chiang rai, thailand," Journal of Acquired Immune Deficiency Syndromes, vol. 49, no. 1, pp. 7783, 2008.

[17] J. M. Baeten, L. B. Strick, A. Lucchetti et al., "Herpes simplex virus (HSV)-suppressive therapy decreases plasma and genital HIV-1 levels in HSV-2/HIV-1 coinfected women: a randomized, placebo-controlled, cross-over trial," Journal of Infectious Diseases, vol. 198, no. 12, pp. 1804-1808, 2008.

[18] S. Delany, N. Mlaba, T. Clayton et al., "Impact of aciclovir on genital and plasma HIV-1 RNA in HSV-2/HIV-1 co-infected women: a randomized placebo-controlled trial in South Africa," AIDS, vol. 23, no. 4, pp. 461-469, 2009.

[19] C. Celum, A. Wald, J. R. Lingappa et al., "Acyclovir and transmission of HIV-1 from persons infected with HIV-1 and HSV-2," The New England Journal of Medicine, vol. 362, no. 5, pp. 427439, 2010.

[20] C. Tanton, H. A. Weiss, M. Rusizoka et al., "Long-term impact of acyclovir suppressive therapy on genital and plasma HIV RNA in Tanzanian women: a randomized controlled trial," Journal of Infectious Diseases, vol. 201, no. 9, pp. 1285-1297, 2010.

[21] K. Mugwanya, J. M. Baeten, N. R. Mugo, E. Irungu, K. Ngure, and C. Celum, "High-dose valacyclovir HSV-2 suppression results in greater reduction in plasma HIV-1 levels compared with standard dose acyclovir among HIV-1/HSV-2 coinfected persons: a randomized, crossover trial," Journal of Infectious Diseases, vol. 204, no. 12, pp. 1912-1917, 2011.
[22] A. Ouedraogo, N. Nagot, L. Vergne et al., "Impact of suppressive herpes therapy on genital HIV-1 RNA among women taking antiretroviral therapy: a randomized controlled trial," AIDS, vol. 20, no. 18, pp. 2305-2313, 2006.

[23] J. R. Lingappa, J. M. Baeten, A. Wald et al., "Daily aciclovir for HIV-1 disease progression in people dually infected with HIV1 and herpes simplex virus type 2: a randomised placebo-controlled trial," The Lancet, vol. 375, no. 9717, pp. 824-833, 2010.

[24] S. J. Reynolds, F. Makumbi, K. Newell et al., "Effect of daily aciclovir on HIV disease progression in individuals in Rakai, Uganda, co-infected with HIV-1 and herpes simplex virus type 2: a randomised, double-blind placebo-controlled trial," The Lancet Infectious Diseases, 2012.

[25] L. Mole, S. Ripich, D. Margolis, and M. Holodniy, “The impact of active herpes simplex virus infection on human immunodeficiency virus load," Journal of Infectious Diseases, vol. 176, no. 3, pp. 766-770, 1997.

[26] J. M. Baeten, R. S. McClelland, L. Corey et al., "Vitamin A supplementation and genital shedding of herpes simplex virus among HIV-1-infected women: a randomized clinical trial," Journal of Infectious Diseases, vol. 189, no. 8, pp. 1466-1471, 2004.

[27] D. Serwadda, R. H. Gray, N. K. Sewankambo et al., "Human immunodeficiency virus acquisition associated with genital ulcer disease and herpes simplex virus type 2 infection: a nested case-control study in Rakai, Uganda," Journal of Infectious Diseases, vol. 188, no. 10, pp. 1492-1497, 2003.

[28] C. Ludema, S. R. Cole, C. Poole, H. Chu, and J. J. Eron, "Metaanalysis of randomized trials on the association of prophylactic acyclovir and HIV-1 viral load in individuals coinfected with herpes simplex virus-2," AIDS, vol. 25, no. 10, pp. 1265-1269, 2011.

[29] A. Lisco, C. Vanpouille, E. P. Tchesnokov et al., "Acyclovir is activated into a HIV-1 reverse transcriptase inhibitor in herpesvirus-infected human tissues," Cell Host and Microbe, vol. 4, no. 3, pp. 260-270, 2008.

[30] M. A. McMahon, J. D. Siliciano, J. Lai et al., "The antiherpetic drug acyclovir inhibits HIV replication and selects the V75I reverse transcriptase multidrug resistance mutation," Journal of Biological Chemistry, vol. 283, no. 46, pp. 31289-31293, 2008.

[31] M. A. McMahon, T. L. Parsons, L. Shen, J. D. Siliciano, and R. F. Siliciano, "Consistent inhibition of HIV-1 replication in CD4+ T cells by acyclovir without detection of human herpesviruses," Journal of Virology, vol. 85, no. 9, pp. 4618-4622, 2011.

[32] J. W. Mellors, C. R. Rinaldo Jr., P. Gupta, R. M. White, J. A. Todd, and L. A. Kingsley, "Prognosis in HIV-1 infection predicted by the quantity of virus in plasma," Science, vol. 272, no. 5265, pp. 1167-1170, 1996.

[33] K. Modjarrad, E. Chamot, and S. H. Vermund, "Impact of small reductions in plasma HIV RNA levels on the risk of heterosexual transmission and disease progression," AIDS, vol. 22, no. 16, pp. 2179-2185, 2008.

[34] J. P. A. Ioannidis, A. C. Collier, D. A. Cooper et al., "Clinical efficacy of high-dose acyclovir in patients with human immunodeficiency virus infection: a meta-analysis of randomized individual patient data," Journal of Infectious Diseases, vol. 178, no. 2, pp. 349-359, 1998.

[35] H. N. Kim, J. Wang, J. Hughes et al., "Effect of acyclovir on HIV-1 set point among herpes simplex virus type 2 seropositive persons during early HIV-1 infection," Journal of Infectious Diseases, vol. 202, no. 5, pp. 734-738, 2010.

[36] R. J. C. Gilson, A. E. Hawkins, M. R. Beecham et al., "Interactions between HIV and hepatitis B virus in homosexual men: 
effects on the natural history of infection," AIDS, vol. 11, no. 5, pp. 597-606, 1997.

[37] S. E. Kellerman, D. L. Hanson, A. D. McNaghten, and P. L. Fleming, "Prevalence of chronic hepatitis B and incidence of acute hepatitis B infection in human immunodeficiency virusinfected subjects," Journal of Infectious Diseases, vol. 188, no. 4, pp. 571-577, 2003.

[38] V. Soriano, P. Barreiro, L. Martin-Carbonero et al., “Treatment of chronic hepatitis B or C in HIV-infected patients with dual viral hepatitis," Journal of Infectious Diseases, vol. 195, no. 8, pp. 1181-1183, 2007.

[39] R. Weber, C. A. Sabin, N. Friis-Møller et al., "Liver-related deaths in persons infected with the human immunodeficiency virus the D:A:D study," Archives of Internal Medicine, vol. 166, no. 15, pp. 1632-1641, 2006.

[40] M. J. Alter, "Epidemiology of viral hepatitis and HIV co-infection," Journal of Hepatology, vol. 44, no. 1, pp. S6-S9, 2006.

[41] G. Mathews and S. Bhagani, "The epidemiology and natural history of HIV/HBV and HIV/HCV co-infections," Journal of HIV therapy, vol. 8, no. 4, pp. 77-84, 2003.

[42] C. L. Thio, E. C. Seaberg, R. Skolasky Jr. et al., "HIV-1, hepatitis $\mathrm{B}$ virus, and risk of liver-related mortality in the Multicenter Cohort Study (MACS)," The Lancet, vol. 360, no. 9349, pp. 19211926, 2002.

[43] C. L. Thio, "Hepatitis B and human immunodeficiency virus coinfection," Hepatology, vol. 49, no. 5, pp. S138-S145, 2009.

[44] M. S. Sulkowski, D. L. Thomas, R. E. Chaisson, and R. D. Moore, "Hepatotoxicity associated with antiretroviral therapy in adults infected with human immunodeficiency virus and the role of hepatitis C or B virus infection," Journal of the American Medical Association, vol. 283, no. 1, pp. 74-80, 2000.

[45] M. Puoti, C. Torti, R. Bruno, G. Filice, and G. Carosi, "Natural history of chronic hepatitis B in co-infected patients," Journal of Hepatology, vol. 44, no. 1, pp. S65-S70, 2006.

[46] D. Konopnicki, A. Mocroft, S. De Wit et al., "Hepatitis B and HIV: prevalence, AIDS progression, response to highly active antiretroviral therapy and increased mortality in the EuroSIDA cohort," AIDS, vol. 19, no. 6, pp. 593-601, 2005.

[47] L. H. Omland, N. Weis, P. Skinhøj et al., "Impact of hepatitis $\mathrm{B}$ virus co-infection on response to highly active antiretroviral treatment and outcome in HIV-infected individuals: a nationwide cohort study," HIV Medicine, vol. 9, no. 5, pp. 300-306, 2008.

[48] C. J. Hoffmann, E. C. Seaberg, S. Young et al., "Hepatitis B and long-term HIV outcomes in coinfected HAART recipients," AIDS, vol. 23, no. 14, pp. 1881-1889, 2009.

[49] C. J. Hoffmann, S. Charalambous, D. J. Martin et al., "Hepatitis $B$ virus infection and response to antiretroviral therapy (ART) in a South African ART Program," Clinical Infectious Diseases, vol. 47, no. 11, pp. 1479-1485, 2008.

[50] S. E. lsa, L. N. Gwamzhi, C. Akolo, and J. Giyan, "A prospective cohort study of immunologic and virologic outcomes in patients with HIV/AIDS and hepatitis virus co-infection in Jos, Nigeria," Nigerian Journal of Medicine, vol. 19, no. 3, pp. 279-285, 2010.

[51] D. Lincoln, K. Petoumenos, G. J. Dore et al., "HIV/HBV and HIV/HCV coinfection, and outcomes following highly active antiretroviral therapy," HIV Medicine, vol. 4, no. 3, pp. 241-249, 2003.

[52] E. Moore, M. B. J. Beadsworth, M. Chaponda et al., "Favourable one-year ART outcomes in adult Malawians with hepatitis B and C co-infection," Journal of Infection, vol. 61, no. 2, pp. 155$163,2010$.

[53] J. Idoko, S. Meloni, M. Muazu et al., "Impact of hepatitis b virus infection on human immunodeficiency virus response to antiretroviral therapy in Nigeria," Clinical Infectious Diseases, vol. 49, no. 8, pp. 1268-1273, 2009.

[54] W.-H. Sheng, M.-Y. Chen, S.-M. Hsieh et al., "Impact of chronic hepatitis B virus (HBV) Infection on outcomes of patients infected with HIV in an area where HBV infection is hyperendemic," Clinical Infectious Diseases, vol. 38, no. 10, pp. 1471-1477, 2004.

[55] C. Hawkins, B. Christian, J. Ye et al., "Prevalence of Hepatitis B co-infection and response to antiretroviral therapy among HIVinfected patients in urban Tanzania," AIDS, vol. 27, pp. 919-927, 2012.

[56] A. de Luca, R. Bugarinin, A. C. Lepri et al., "Coinfection with hepatitis viruses and outcome of initial antiretroviral regimens in previously naïve HIV-infected subjects," Archives of Internal Medicine, vol. 162, no. 18, pp. 2125-2132, 2002.

[57] G. V. Matthews, P. Manzini, Z. Hu et al., "Impact of lamivudine on HIV and hepatitis B virus-related outcomes in HIV/hepatitis $B$ virus individuals in a randomized clinical trial of antiretroviral therapy in southern Africa," AIDS, vol. 25, no. 14, pp. 1727$1735,2011$.

[58] A. Eskild, P. Magnus, G. Petersen et al., "Hepatitis B antibodies in HIV-infected homosexual men are associated with more rapid progression to AIDS," AIDS, vol. 6, no. 6, pp. 571-574, 1992.

[59] B. F. Scharschmidt, M. J. Held, H. H. Hollander et al., "Hepatitis B in patients with HIV infection: relationship to AIDS and patient survival," Annals of Internal Medicine, vol. 117, no. 10, pp. 837-838, 1992.

[60] A. Sinicco, R. Raiteri, M. Sciandra et al., "Coinfection and superinfection of hepatitis B virus in patients infected with human immunodeficiency virus: no evidence of faster progression to AIDS," Scandinavian Journal of Infectious Diseases, vol. 29, no. 2, pp. 111-115, 1997.

[61] R. E. Solomon, M. VanRaden, R. A. Kaslow et al., "Association of hepatitis B surface antigen and core antibody with acquisition and manifestations of human immunodeficiency virus type 1 (HIV-1) infection," American Journal of Public Health, vol. 80, no. 12, pp. 1475-1478, 1990.

[62] D. Greenspan, J. S. Greenspan, G. OVerby et al., "Risk factors for rapid progression from hairy leukoplakia to AIDS: a nested case-control study," Journal of Acquired Immune Deficiency Syndromes, vol. 4, no. 7, pp. 652-658, 1991.

[63] J. Ockenga, H. L. Tillmann, C. Trautwein, M. Stoll, M. P. Manns, and R. E. Schmidt, "Hepatitis B and C in HIV-infected patients: prevalence and prognostic value," Journal of Hepatology, vol. 27, no. 1, pp. 18-24, 1997.

[64] H. M. Chun, A. M. Fieberg, K. H. Hullsiek et al., "Epidemiology of hepatitis B virus infection in a US cohort of HIV-infected individuais during the past 20 years," Clinical Infectious Diseases, vol. 50, no. 3, pp. 426-436, 2010.

[65] H. Wang, Y. Li, C. Zhang et al., "Immunological and virological responses to combined antiretroviral therapy in HIV/hepatitis $\mathrm{B}$ virus-coinfected patients from a multicenter cohort," AIDS, vol. 26, pp. 1755-1763, 2012.

[66] C. L. Thio, L. Smeaton, M. Saulynas et al., "Characterization of HIV-HBV coinfection in a multinational HIV-infected cohort," AIDS, vol. 27, pp. 191-201, 2013. 
[67] W. P. Law, C. J. Duncombe, A. Mahanontharit et al., "Impact of viral hepatitis co-infection on response to antiretroviral therapy and HIV disease progression in the HIV-NAT cohort," AIDS, vol. 18, no. 8, pp. 1169-1177, 2004.

[68] J. W. Cohen Stuart, M. Velema, R. Schuurman, C. A. B. Boucher, and A. I. M. Hoepelman, "Occult hepatitis B in persons infected with HIV is associated with low CD4 counts and resolves during antiretroviral therapy," Journal of Medical Virology, vol. 81, no. 3, pp. 441-445, 2009.

[69] D. Chadwick, A. Stanley, S. Sarfo et al., "Response to antiretroviral therapy in occult hepatitis B and HIV co-infection in West Africa," AIDS, vol. 27, pp. 139-144, 2013.

[70] E. Seto, T. S. B. Yen, B. M. Peterlin, and J.-H. Ou, "Trans-activation of the human immunodeficiency virus long terminal repeat by the hepatitis B virus X protein," Proceedings of the National Academy of Sciences of the United States of America, vol. 85, no. 21, pp. 8286-8290, 1988.

[71] J.-S. Twu, K. Chu, and W. S. Robinson, "Hepatitis B virus X gene activates $\kappa \mathrm{B}$-like enhancer sequences in the long terminal repeat of human immunodeficiency virus 1," Proceedings of the National Academy of Sciences of the United States of America, vol. 86, no. 13, pp. 5168-5172, 1989.

[72] J.-S. Twu, C. A. Rosen, W. A. Haseltine, and W. S. Robinson, "Identification of a region within the human immunodeficiency virus type 1 long terminal repeat that is essential for transactivation by the hepatitis B virus gene X," Journal of Virology, vol. 63, no. 6, pp. 2857-2860, 1989.

[73] G. K. Nikolopoulos, D. Paraskevis, E. Hatzitheodorou et al., "Impact of hepatitis B virus infection on the progression of AIDS and mortality in HIV-infected individuals: a cohort study and meta-analysis," Clinical Infectious Diseases, vol. 48, no. 12, pp. 1763-1771, 2009.

[74] G. Wandeler, T. Gsponer, A. Bregenzer et al., "Hepatitis C virus infections in the Swiss HIV Cohort Study: a rapidly evolving epidemic," Clinical Infectious Diseases, vol. 55, pp. 1408-1416, 2012.

[75] T. van de Laar, O. Pybus, S. Bruisten et al., "Evidence of a large, international network of HCV transmission in HIV-positive men who have sex with men," Gastroenterology, vol. 136, no. 5, pp. 1609-1617, 2009.

[76] A. Briat, E. Dulioust, J. Galimand et al., "Hepatitis C virus in the semen of men coinfected with HIV-1: prevalence and origin," AIDS, vol. 19, no. 16, pp. 1827-1835, 2005.

[77] H.-H. Thein, Q. Yi, G. J. Dore, and M. D. Krahn, "Natural history of hepatitis $\mathrm{C}$ virus infection in HIV-infected individuals and the impact of HIV in the era of highly active antiretroviral therapy: a meta-analysis," AIDS, vol. 22, no. 15, pp. 1979-1991, 2008.

[78] C. Smit, C. Van Den Berg, R. Geskus, B. Berkhout, R. Coutinho, and M. Prins, "Risk of hepatitis-related mortality increased among hepatitis $\mathrm{C}$ virus/HIV-coinfected drug users compared with drug users infected only with hepatitis C virus: a 20 -year prospective study," Journal of Acquired Immune Deficiency Syndromes, vol. 47, no. 2, pp. 221-225, 2008.

[79] Y. Rotman and T. J. Liang, "Coinfection with hepatitis C virus and human immunodeficiency virus: virological, immunological, and clinical outcomes," Journal of Virology, vol. 83, no. 15, pp. 7366-7374, 2009.

[80] B. Roe and W. W. Hall, "Cellular and molecular interactions in coinfection with hepatitis $\mathrm{C}$ virus and human immunodeficiency virus," Expert Reviews in Molecular Medicine, vol. 10, no. 30, article e30, pp. 1-19, 2008.
[81] A. Y. Kim and R. T. Chung, "Coinfection with HIV-1 and HCV-a one-two punch," Gastroenterology, vol. 137, no. 3, pp. 795-814, 2009.

[82] T. Kuntzen, C. Tural, B. Li et al., "Intrahepatic mRNA expression in hepatitis $\mathrm{C}$ virus and HIV/hepatitis $\mathrm{C}$ virus co-infection: infiltrating cells, cytokines, and influence of HAART," AIDS, vol. 22, no. 2, pp. 203-210, 2008.

[83] N. Nakamoto, D. E. Kaplan, J. Coleclough et al., "Functional restoration of HCV-specific CD8 T cells by PD-1 blockade is defined by PD-1 expression and compartmentalization," Gastroenterology, vol. 134, no. 7, pp. 1927-e2, 2008.

[84] J. T. Blackard and K. E. Sherman, "HCV/HIV co-infection: time to re-evaluate the role of HIV in the liver?" Journal of Viral Hepatitis, vol. 15, no. 5, pp. 323-330, 2008.

[85] A. C. Tuyama, F. Hong, Y. Saiman et al., "Human immunodeficiency virus (HIV)-1 infects human hepatic stellate cells and promotes collagen I and monocyte chemoattractant protein-1 expression: implications for the pathogenesis of HIV/hepatitis C virus-induced liver fibrosis," Hepatology, vol. 52, no. 2, pp. 612-622, 2010.

[86] N. Merchante, A. Rivero, I. De Los Santos-Gil et al., "Insulin resistance is associated with liver stiffness in $\mathrm{HIV} / \mathrm{HCV}$ coinfected patients," Gut, vol. 58, no. 12, pp. 1654-1660, 2009.

[87] P. Halfon, G. Pénaranda, F. Carrat et al., "Influence of insulin resistance on hepatic fibrosis and steatosis in hepatitis $\mathrm{C}$ virus (HCV) mono-infected compared with HIV-HCV co-infected patients," Alimentary Pharmacology and Therapeutics, vol. 30, no. 1, pp. 61-70, 2009.

[88] T.-Y. Chen, E. L. Ding, G. R. Seage III, and A. Y. Kim, "Metaanalysis: increased mortality associated with hepatitis $\mathrm{C}$ in HIV-infected persons is unrelated to HIV disease progression," Clinical Infectious Diseases, vol. 49, no. 10, pp. 1605-1615, 2009.

[89] A. d'Arminio Monforte, A. Cozzi-Lepri, A. Castagna et al., "Risk of developing specific aids-defining illnesses in patients coinfected with HIV and hepatitis c virus with or without liver cirrhosis," Clinical Infectious Diseases, vol. 49, no. 4, pp. 612-622, 2009.

[90] A. Kovacs, R. Karim, W. J. Mack et al., "Activation of CD8 T cells predicts progression of HIV infection in women coinfected with hepatitis C virus," Journal of Infectious Diseases, vol. 201, no. 6, pp. 823-834, 2010.

[91] A. Kovacs, L. Al-Harthi, S. Christensen, W. Mack, M. Cohen, and A. Landay, "CD8+ T cell activation in women coinfected with human immunodeficiency virus type 1 and hepatitis C virus," Journal of Infectious Diseases, vol. 197, no. 10, pp. 14021407, 2008.

[92] V. D. Gonzalez, K. Falconer, K. G. Blom et al., "High levels of chronic immune activation in the T-cell compartments of patients coinfected with hepatitis $\mathrm{C}$ virus and human immunodeficiency virus type 1 and on highly active antiretroviral therapy are reverted by alpha interferon and ribavirin treatment," Journal of Virology, vol. 83, no. 21, pp. 11407-11411, 2009.

[93] C. Körner, B. Krämer, D. Schulte et al., "Effects of HCV co-infection on apoptosis of CD4+ T-cells in HIV-positive patients," Clinical Science, vol. 116, pp. 861-870, 2009.

[94] M. Potter, A. Odueyungbo, H. Yang, S. Saeed, and M. B. Klein, "Impact of hepatitis C viral replication on CD4+ T-lymphocyte progression in HIV-HCV coinfection before and after antiretroviral therapy," AIDS, vol. 24, no. 12, pp. 1857-1865, 2010.

[95] L. Peters, A. Mocroft, V. Soriano et al., "Hepatitis C virus coinfection does not influence the CD4 cell recovery in HIV-1infected patients with maximum virologic suppression," Journal 
of Acquired Immune Deficiency Syndromes, vol. 50, no. 5, pp. 457-463, 2009.

[96] K. Yacisin, I. Maida, M. J. Ríos, V. Soriano, and M. Núñez, "Hepatitis $\mathrm{C}$ virus coinfection does not affect $\mathrm{CD} 4$ restoration in HIV-infected patients after initiation of antiretroviral therapy," AIDS Research and Human Retroviruses, vol. 24, no. 7, pp. 935940, 2008.

[97] L. Al-Harthi, J. Voris, W. Du et al., "Evaluating the impact of hepatitis $\mathrm{C}$ virus (HCV) on highly active antiretroviral therapymediated immune responses in HCV/HIV-coinfected women: role of HCV on expression of primed/memory T cells," Journal of Infectious Diseases, vol. 193, no. 9, pp. 1202-1210, 2006.

[98] P. S. Sullivan, D. L. Hanson, E. H. Teshale, L. L. Wotring, and J. T. Brooks, "Effect of hepatitis $\mathrm{C}$ infection on progression of HIV disease and early response to initial antiretroviral therapy," AIDS, vol. 20, no. 8, pp. 1171-1179, 2006.

[99] M. S. Sulkowski, "Management of hepatic complications in HIV-infected persons," Journal of Infectious Diseases, vol. 197, no. 3, pp. S279-S293, 2008.

[100] J. F. Pascual-Pareja, A. Caminoa, J. Larrauri et al., "HAART is associated with lower hepatic necroinflammatory activity in HIV-hepatitis $\mathrm{C}$ virus-coinfected patients with CD4 cell count of more than 350 cells/ $\mu$ l at the time of liver biopsy," AIDS, vol. 23, no. 8, pp. 971-975, 2009.

[101] E. E. M. Moodie, N. P. Pai, and M. B. Klein, "Is antiretroviral therapy causing long-term liver damage? A comparative analysis of HIV-mono-infected and HIV/hepatitis C co-infected cohorts," PLoS ONE, vol. 4, no. 2, Article ID e4517, 2009.

[102] M. A. Thompson, J. A. Aberg, J. F. Hoy et al., "Antiretroviral treatment of adult HIV infection: 2012 recommendations of the International Antiviral Society-USA panel," Journal of the American Medical Association, vol. 308, pp. 387-402, 2012.

[103] P. V. Chin-Hong and J. M. Palefsky, "Natural history and clinical management of anal human papillomavirus disease in men and women infected with human immunodeficiency virus," Clinical Infectious Diseases, vol. 35, no. 9, pp. 1127-1134, 2002.

[104] S. Thavaraj, A. Stokes, E. Guerra et al., "Evaluation of human papillomavirus testing for squamous cell carcinoma of the tonsil in clinical practice," Journal of Clinical Pathology, vol. 64, no. 4, pp. 308-312, 2011.

[105] R. Faridi, A. Zahra, K. Khan, and M. Idrees, "Oncogenic potential of human papillomavirus (HPV) and its relation with cervical cancer," Virology Journal, vol. 8, article 269, 2011.

[106] J. M. Palefsky, "Anal cancer prevention in HIV-positive men and women," Current Opinion in Oncology, vol. 21, no. 5, pp. 433438, 2009.

[107] T. Rosen and J. H. Spedale, "Relationships between sexually transmitted diseases and human immunodeficiency virus infection," Current Problems in Dermatology, vol. 9, no. 6, pp. 242262, 1997.

[108] A. R. Garbuglia, P. Piselli, D. Lapa et al., "Frequency and multiplicity of human papillomavirus infection in HIV-1 positive women in Italy," Journal of Clinical Virology, vol. 54, no. 2, pp. 141-146, 2012.

[109] S. G. Parisi, M. Cruciani, R. Scaggiante et al., "Anal and oral human papillomavirus (HPV) infection in HIV-infected subjects in northern Italy: a longitudinal cohort study among men who have sex with men," BMC Infectious Diseases, vol. 11, article 150, 2011.

[110] R. G. Nowak, P. E. Gravitt, C. S. Morrison et al., "Increases in human papillomavirus detection during early HIV infection among women in Zimbabwe," Journal of Infectious Diseases, vol. 203, no. 8, pp. 1182-1191, 2011.

[111] P. A. Fox, "Human papillomavirus and anal intraepithelial neoplasia," Current Opinion in Infectious Diseases, vol. 19, no. 1, pp. 62-66, 2006.

[112] L. Conley, T. Bush, T. M. Darragh et al., "Factors associated with prevalent abnormal anal cytology in a large cohort of HIVinfected adults in the United States," Journal of Infectious Diseases, vol. 202, no. 10, pp. 1567-1576, 2010.

[113] A. S. Baranoski, R. Tandon, J. Weinberg, F. F. Huang, and E. A. Stier, "Risk factors for abnormal anal cytology over time in HIV-infected women," American Journal of Obstetrics and Gynecology, 2012.

[114] N. F. Crum-Cianflone, K. H. Hullsiek, V. C. Marconi et al., "Anal cancers among HIV-infected persons: HAART is not slowing rising incidence," AIDS, vol. 24, no. 4, pp. 535-543, 2010.

[115] C. F. Houlihan, N. L. Larke, D. Watson-Jones et al., "Human papillomavirus infection and increased risk of HIV acquisition. A systematic review and meta-analysis," AIDS, vol. 26, pp. 22112222, 2012.

[116] J. S. Smith, S. Moses, M. G. Hudgens et al., "Increased risk of HIV acquisition among kenyan men with human papillomavirus infection," Journal of Infectious Diseases, vol. 201, no. 11, pp. 1677-1685, 2010.

[117] N. M. Zetola and J. D. Klausner, "Syphilis and HIV infection: an update," Clinical Infectious Diseases, vol. 44, no. 9, pp. 1222-1228, 2007.

[118] J. D. Heffelfinger, E. B. Swint, S. M. Berman, and H. S. Weinstock, "Trends in primary and secondary syphilis among men who have sex with men in the United States," American Journal of Public Health, vol. 97, no. 6, pp. 1076-1083, 2007.

[119] J. R. Su, J. F. Beltrami, A. A. Zaidi, and H. S. Weinstock, "Primary and secondary syphilis among black and hispanic men who have sex with men: case report data from 27 states," Annals of Internal Medicine, vol. 155, no. 3, pp. 145-152, 2011.

[120] X. Zhang, C. Wang, W. Hengwei et al., "Risk factors of HIV infection and prevalence of co-infections among men who have sex with men in Beijing, China," AIDS, vol. 21, no. 8, pp. S53S57, 2007.

[121] T. L. Patterson, S. J. Semple, H. Staines et al., "Prevalence and correlates of HIV infection among female sex workers in 2 Mexico-US border cities," Journal of Infectious Diseases, vol. 197, no. 5, pp. 728-732, 2008.

[122] K. G. Ghanem, R. D. Moore, A. M. Rompalo, E. J. Erbelding, J. M. Zenilman, and K. A. Gebo, "Antiretroviral therapy is associated with reduced serologic failure rates for syphilis among HIV-infected patients," Clinical Infectious Diseases, vol. 47, no. 2, pp. 258-265, 2008.

[123] D. F. Knaute, N. Graf, S. Lautenschlager, R. Weber, and P. P. Bosshard, "Serological response to treatment of syphilis according to disease stage and HIV status," Clinical Infectious Diseases, vol. 55, pp. 1615-1622, 2012.

[124] K. Buchacz, P. Patel, M. Taylor et al., "Syphilis increases HIV viral load and decreases CD4 cell counts in HIV-infected patients with new syphilis infections," AIDS, vol. 18, no. 15, pp. 2075-2079, 2004.

[125] K. Kofoed, J. Gerstoft, L. R. Mathiesen, and T. Benfield, "Syphilis and human immunodeficiency virus (HIV)-1 coinfection: influence on CD4 T-cell count, HIV-1 viral load, and treatment response," Sexually Transmitted Diseases, vol. 33, no. 3, pp. 143148, 2006. 
[126] R. Palacios, F. Jiménez-Oñate, M. Aguilar et al., "Impact of syphilis infection on HIV viral load and CD4 cell counts in HIV-infected patients," Journal of Acquired Immune Deficiency Syndromes, vol. 44, no. 3, pp. 356-359, 2007.

[127] R. Manfredi, S. Sabbatani, D. Pocaterra, L. Calza, and F. Chiodo, "Syphilis does not seem to involve virological and immunological course of concurrent HIV disease," AIDS, vol. 20, no. 2, pp. 305-306, 2006.

[128] S. T. Sadiq, J. McSorley, A. J. Copas et al., "The effects of early syphilis on CD4 counts and HIV-1 RNA viral loads in blood and semen," Sexually Transmitted Infections, vol. 81, no. 5, pp. 380385, 2005.

[129] W. Jarzebowski, E. Caumes, N. Dupin et al., "Effect of early syphilis infection on plasma viral load and CD4 cell count in human immunodeficiency virus-infected men: results from the FHDH-ANRS CO4 cohort," Arch Intern Med, vol. 172, no. 16, pp. 1237-1243, 2012.

[130] S. A. Theus, D. A. Harrich, R. Gaynor, J. D. Radolf, and M. V. Norgard, "Treponema pallidum, lipoproteins, and synthetic lipoprotein analogues induce human immunodeficiency virus type 1 gene expression in monocytes via NF- $\kappa$ B activation," Journal of Infectious Diseases, vol. 177, no. 4, pp. 941-950, 1998.

[131] A. C. Weintrob, W. Gu, J. Qin et al., "Syphilis co-infection does not affect HIV disease progression," International Journal of STD and AIDS, vol. 21, no. 1, pp. 57-59, 2010.

[132] C. K. Kent, J. K. Chaw, W. Wong et al., "Prevalence of rectal, urethral, and pharyngeal chlamydia and gonorrhea detected in 2 clinical settings among men who have sex with men: San Francisco, California, 2003," Clinical Infectious Diseases, vol. 41, no. 1, pp. 67-74, 2005.

[133] M. Johansson, K. Schön, M. Ward, and N. Lycke, "Studies in knockout mice reveal that anti-chlamydial protection requires TH1 cells producing IFN- $\gamma$ : is this true for humans?" Scandinavian Journal of Immunology, vol. 46, no. 6, pp. 546-552, 1997.

[134] R. G. Rank, L. S. F. Soderberg, and A. L. Barron, "Chronic chlamydial genital infection in congenitally athymic nude mice," Infection and Immunity, vol. 48, no. 3, pp. 847-849, 1985.

[135] S. Wang, Y. Fan, R. C. Brunham, and X. Yang, "IFN-gamma knockout mice show Th2-associated delayed-type hypersensitivity and the inflammatory cells fail to localize and control chlamydial infection," European Journal of Immunology, vol. 29, pp. 3782-3792, 1999.

[136] C. R. Cohen, R. Nguti, E. A. Bukusi et al., "Human immunodeficiency virus type 1-infected women exhibit reduced interferon$\gamma$ secretion after Chlamydia trachomatis stimulation of peripheral blood lymphocytes," Journal of Infectious Diseases, vol. 182, no. 6, pp. 1672-1677, 2000.

[137] M. S. Cohen, I. F. Hoffman, R. A. Royce et al., "Reduction of concentration of HIV-1 in semen after treatment of urethritis: implications for prevention of sexual transmission of HIV-1," The Lancet, vol. 349, no. 9069, pp. 1868-1873, 1996.

[138] S. T. Sadiq, S. Taylor, A. J. Copas et al., "The effects of urethritis on seminal plasma HIV-1 RNA loads in homosexual men not receiving antiretroviral therapy," Sexually Transmitted Infections, vol. 81, no. 2, pp. 120-123, 2005.

[139] S. T. Sadiq, S. Taylor, S. Kaye et al., "The effects of antiretroviral therapy on HIV-1 RNA loads in seminal plasma in HIV-positive patients with and without urethritis," AIDS, vol. 16, no. 2, pp. 219-225, 2002.
[140] G. Rieg, D. M. Butler, D. M. Smith, and E. S. Daar, "Seminal plasma HIV levels in men with asymptomatic sexually transmitted infections," International Journal of STD and AIDS, vol. 21, no. 3, pp. 207-208, 2010.

[141] C. F. Kelley, R. E. Haaland, P. Patel et al., "HIV-1 RNA rectal shedding is reduced in Men with Low plasma HIV-1 RNA viral loads and is not enhanced by sexually transmitted bacterial infections of the rectum," Journal of Infectious Diseases, vol. 204, no. 5, pp. 761-767, 2011.

[142] J. N. Nkengasong, L. Kestens, P. D. Ghys et al., "Human immunodeficiency virus type 1 (HIV-1) plasma virus load and markers of immune activation among HIV-infected female sex workers with sexually transmitted diseases in Abidjan, Côte d'Ivoire," Journal of Infectious Diseases, vol. 183, no. 9, pp. 14051408, 2001.

[143] A. O. Anzala, J. N. Simonsen, J. Kimani et al., "Acute sexually transmitted infections increase human immunodeficiency virus type 1 plasma viremia, increase plasma type 2 cytokines, and decrease CD4 cell counts," Journal of Infectious Diseases, vol. 182, no. 2, pp. 459-466, 2000.

[144] A. C. Gerbase, J. T. Rowley, D. H. L. Heymann, S. F. B. Berkley, and P. Piot, "Global prevalence and incidence estimates of selected curable STDS," Sexually Transmitted Infections, vol. 74, no. 1, pp. S12-S16, 1998.

[145] V. J. Johnston and D. C. Mabey, "Global epidemiology and control of Trichomonas vaginalis," Current Opinion in Infectious Diseases, vol. 21, no. 1, pp. 56-64, 2008.

[146] L. H. Bachmann, M. M. Hobbs, A. C. Seña et al., "Trichomonas vaginalis genital infections: progress and challenges," Clinical Infectious Diseases, vol. 53, supplement 3, pp. S160-S172, 2011.

[147] World Health Organization, "Global prevalence and incidence of selected curable sexually transmitted infections," Geneva, Switzerland, 2001, http://www.who.int/hiv/pub/sti/ who_hiv_aids_2001.02.pdf.

[148] S. C. Shafir, F. J. Sorvillo, and L. Smith, "Current issues and considerations regarding Trichomoniasis and human immunodeficiency virus in African-Americans," Clinical Microbiology Reviews, vol. 22, no. 1, pp. 37-45, 2009.

[149] S. Cu-Uvin, H. Ko, D. J. Jamieson et al., "Prevalence, incidence, and persistence or recurrence of trichomoniasis among human immunodeficiency virus (HIV)-positive women and among HIV-negative women at high risk for HIV infection," Clinical Infectious Diseases, vol. 34, no. 10, pp. 1406-1411, 2002.

[150] M. Gatski, D. H. Martin, R. A. Clark, E. Harville, N. Schmidt, and P. Kissinger, "Co-occurrence of Trichomonas vaginalis and bacterial vaginosis among hiv-positive women," Sexually Transmitted Diseases, vol. 38, no. 3, pp. 163-166, 2011.

[151] J. R. Schwebke, “Trichomoniasis in adolescents: a marker for the lack of a public health response to the epidemic of sexually transmitted diseases in the United States," Journal of Infectious Diseases, vol. 192, no. 12, pp. 2036-2038, 2005.

[152] H. Swygard, A. C. Seña, M. M. Hobbs, and M. S. Cohen, "Trichomoniasis: clinical manifestations, diagnosis and management," Sexually Transmitted Infections, vol. 80, no. 2, pp. 91-95, 2004.

[153] I. T. Gram, M. Macaluso, J. Churchill, and H. Stalsberg, "Trichomonas vaginalis (TV) and human papillomavirus (HPV) infection and the incidence of cervical intraepithelial neoplasia (CIN) grade III," Cancer Causes and Control, vol. 3, no. 3, pp. 231-236, 1992.

[154] H. W. Chesson, J. M. Blandford, and S. D. Pinkerton, "Estimates of the annual number and cost of new HIV infections among 
women attributable to trichomoniasis in the United States," Sexually Transmitted Diseases, vol. 31, no. 9, pp. 547-551, 2004.

[155] R. S. McClelland, L. Sangaré, W. M. Hassan et al., "Infection with Trichomonas vaginalis increases the risk of HIV-1 acquisition," Journal of Infectious Diseases, vol. 195, no. 5, pp. 698-702, 2007.

[156] S. N. Mavedzenge, B. Van Der Pol, H. Cheng et al., "Epidemiological synergy of Trichomonas vaginalis and HIV in Zimbabwean and South African women," Sexually Transmitted Diseases, vol. 37, no. 7, pp. 460-466, 2010.

[157] I. Kleinschmidt, H. Rees, S. Delany et al., "Injectable progestin contraceptive use and risk of HIV infection in a South African family planning cohort," Contraception, vol. 75, no. 6, pp. 461467, 2007.

[158] T. C. Quinn, M. J. Wawer, N. Sewankambo et al., "Viral load and heterosexual transmission of human immunodeficiency virus type 1," The New England Journal of Medicine, vol. 342, no. 13, pp. 921-929, 2000.

[159] J.-A. Røttingen, W. D. Cameron, and G. P. Garnett, "A systematic review of the epidemiologic interactions between classic sexually transmitted diseases and HIV: how much really is known?" Sexually Transmitted Diseases, vol. 28, no. 10, pp. 579-597, 2001.

[160] E. B. Quinlivan, S. N. Patel, C. A. Grodensky, C. E. Golin, H. C. Tien, and M. M. Hobbs, "Modeling the impact of Trichomonas vaginalis infection on HIV transmission in HIV-infected individuals in medical care," Sexually Transmitted Diseases, vol. 39, no. 9, pp. 671-677, 2012.

[161] F. Sorvillo, L. Smith, P. Kerndt, and L. Ash, "Trichomonas vaginalis, HIV, and African-Americans," Emerging Infectious Diseases, vol. 7, no. 6, pp. 927-932, 2001.

[162] W. C. Levine, V. Pope, A. Bhoomkar et al., "Increase in endocervical CD4 lymphocytes among women with nonulcerative sexually transmitted diseases," Journal of Infectious Diseases, vol. 177, no. 1, pp. 167-174, 1998.

[163] N. B. Kiviat, J. A. Paavonen, and J. Brockway, "Cytologic manifestations of cervical and vaginal infections. I. Epithelial and inflammatory cellular changes," Journal of the American Medical Association, vol. 253, no. 7, pp. 989-996, 1985.

[164] P. Mirmonsef, L. Krass, A. Landay, and G. T. Spear, “The role of bacterial vaginosis and trichomonas in HIV transmission across the female genital tract," Current HIV Research , vol. 10, pp. 202210, 2012.

[165] T. C. Wright Jr., S. Subbarao, T. V. Ellerbrock et al., "Human immunodeficiency virus 1 expression in the female genital tract in association with cervical inflammation and ulceration," American Journal of Obstetrics and Gynecology, vol. 184, no. 3, pp. 279-285, 2001.

[166] S. D. Lawn, S. Subbarao, T. C. Wright Jr. et al., "Correlation between human immunodeficiency virus type 1 RNA levels in the female genital tract and immune activation associated with ulceration of the cervix," Journal of Infectious Diseases, vol. 181, no. 6, pp. 1950-1956, 2000.

[167] M. A. Price, D. Zimba, I. F. Huffman et al., "Addition of treatment for trichomoniasis to syndromic management of urethritis in Malawi: a randomized clinical trial," Sexually Transmitted Diseases, vol. 30, no. 6, pp. 516-522, 2004.

[168] L. N. Masese, S. M. Graham, R. Gitau et al., "A prospective study of vaginal trichomoniasis and HIV-1 shedding in women on antiretroviral therapy," BMC Infectious Diseases, vol. 11, article 307, 2011.

[169] C. C. Wang, R. S. McClelland, M. Reilly et al., "The effect of treatment of vaginal infections on shedding of human immunodeficiency virus type 1," Journal of Infectious Diseases, vol. 183, no. 7, pp. 1017-1022, 2001.

[170] B. L. Anderson, C. Firnhaber, T. Liu et al., "Effect of trichomoniasis therapy on genital HIV viral burden among African women," Sexually Transmitted Diseases, vol. 39, no. 8, pp. 638642, 2012.

[171] P. Kissinger, A. Amedee, R. A. Clark et al., "Trichomonas vaginalis treatment reduces vaginal HIV-1 shedding," Sexually Transmitted Diseases, vol. 36, no. 1, pp. 11-16, 2009. 


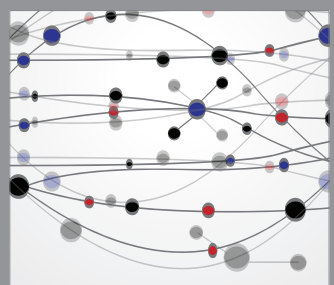

The Scientific World Journal
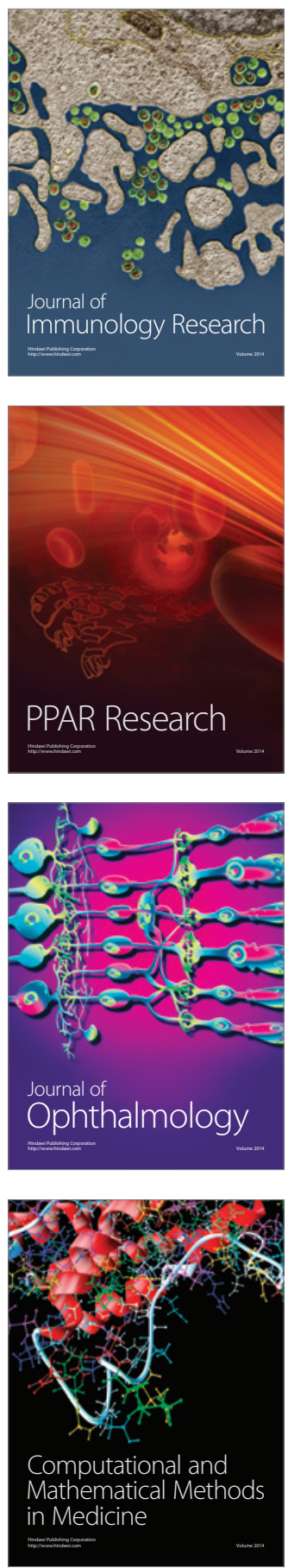

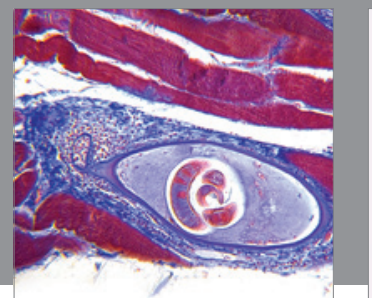

Gastroenterology

Research and Practice
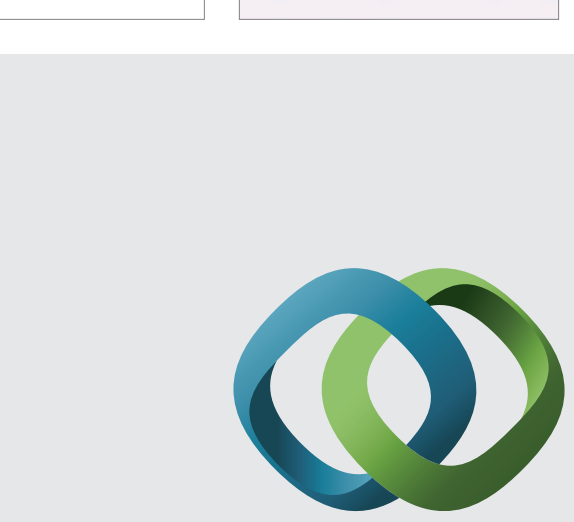

\section{Hindawi}

Submit your manuscripts at

http://www.hindawi.com
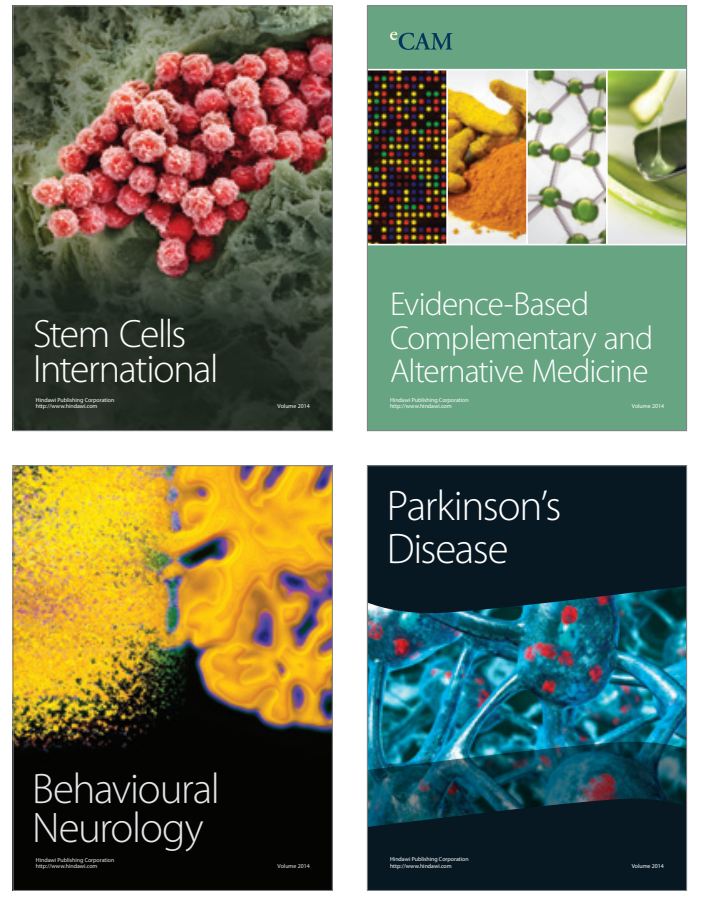
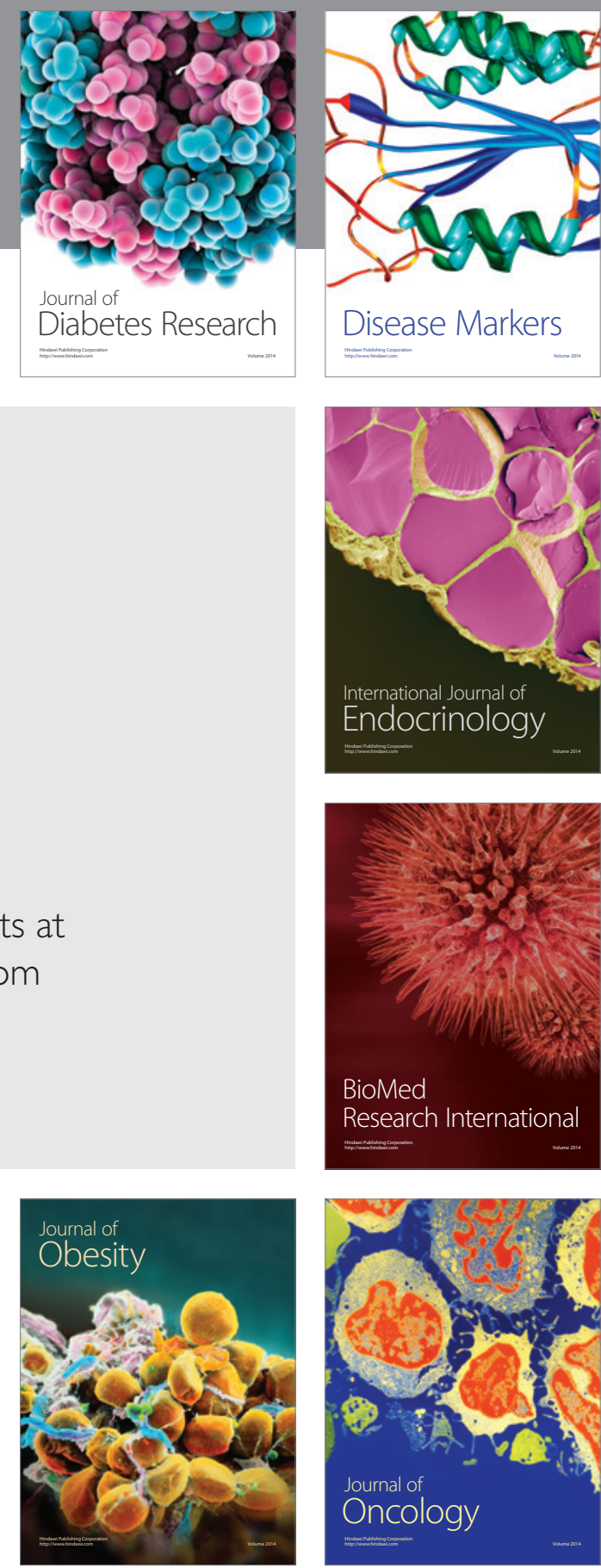

Disease Markers
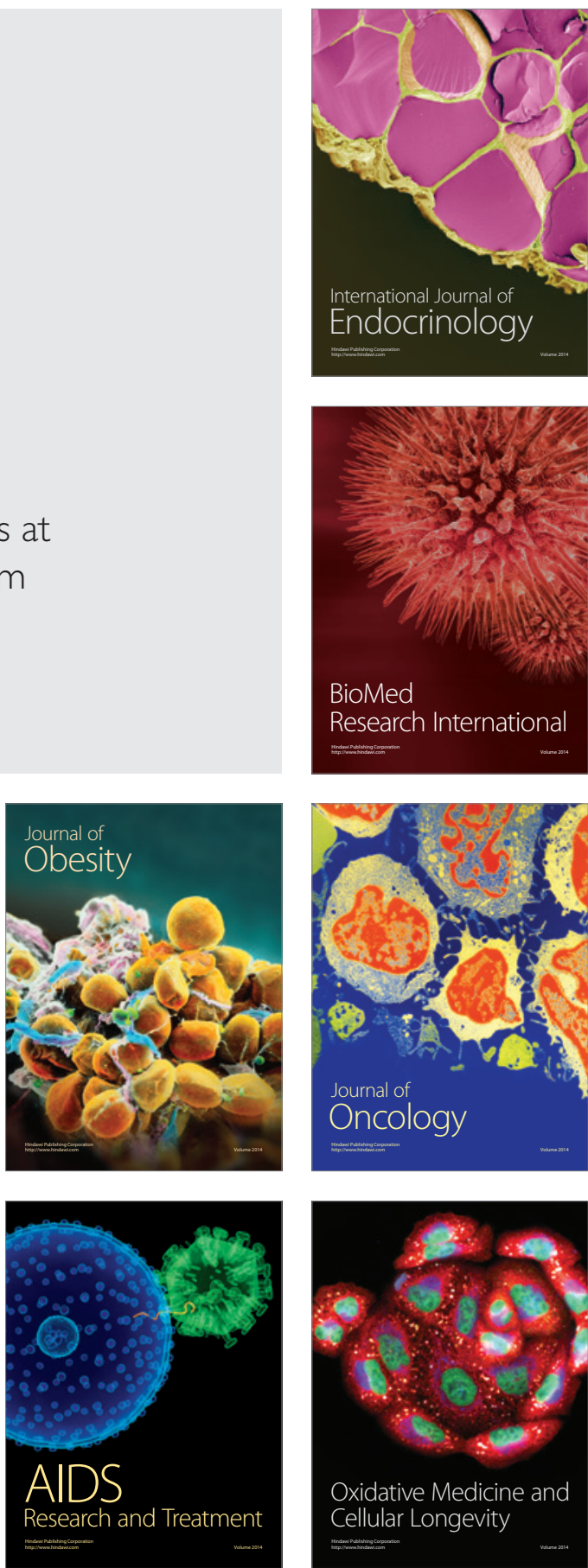